\title{
RECENT ACTIVITY AT NYIRAGONGO AND LAVA-LAKE OCCURRENCES
}

\author{
HAROUN TAZIEFF
}

TAZIEFF, HAROUN, 1985: Recent Activity at Nyiragongo and lava-lake occurrences. Bull. Geol. Soc. Finland 57, Part 1-2, 11-19.

The behaviour of Nyiragongo, before and after its outbreak on January 10th, 1977 , as compared with the behaviour of the other two volcanoes containing subpermanent lava-lakes nowadays, Erta'Ale and Mount Erebus, suggests that the considerable convection necessary to feed such a lake with fresh magma can exist only if wide open fractures intersect at a given spot, thus creating a channel broad enough to allow such a convection. In contrast to Halemaumau, whose lava-lake vanished during the Kilauea eruption in 1924 and has still not reappeared, and Nyamlagira, whose lava-lake was drained out during its long (from 1938 to 1940) eruption, Mount Nyiragongo has resumed this exceptional type of activity a mere five years after its own lake was tapped off. The proposed hypothesis is that the January 1977 outbreak was a »passive» one whereas the 1924 and 1938 eruptions were »active». By active, we mean those which are due to a specific magma eruptivity, that is to say, vesiculation of the gaseous phase previously dissolved in the silicated melt. The outbreak on 10th January 1977 was passive in that both the lava-lake end the underlying magma were flowing out of the volcanic cone when the cone cracked not under its own magma pressure, which in fact had not yet reached vesicular eruptive maturity, but under the subjacent parental magma, pushing up both the Nyiragongo and Nyamlagira volcanoes from beneath.

This hypothesis may explain why at Mount Nyiragongo the magma, once its ascensional force was restored by vesiculation, could easily open a passage wide enough to allow convection: the wide fractures intersecting at the axis of the passage were obstructed only by a very loose mass of rocks fallen from the surrounding slopes, whereas the »upgoing chimneys» of Kilauea and Nyamlagira had been blocked by a massive lava residue, solidified at the end of their nactive» eruption.

The numbers of eruptions produced by these two volcanoes since then have always occured through only one fracture trend. There being no such obstruction in the chimney of Nyiragongo, however the uprising of the magma could start again under geometric conditions, thus permitting the absolutely necessary convection to engender a permanent lava-lake.

Conventional volcanic outbreaks never reveal the bi-phase character.

Key words: magma reservoirs, magma buoancy, twin eruptions, eruptive ripeness, convection.

Haroun Tazieff: Secrétaire d'Etat Chargé de la Prévention des Risques Naturels et Technologiques Majeurs, 41. Quai Branly, 75700 Paris, France. 


\section{Introduction}

Although four years have now passed since I dropped almost all fundamental research for applied, or finalized, volcanology, I willingly accepted the honour awarded me by the Geological Society of Finland to contribute to the present special issue of its Bulletin, dedicated to the memory of my old friend, Thure Sahama.

The first time Thure and I discussed Mount Nyiragongo's exceptional eruptive and petrological characteristics we were standing within this volcano's very active crater; that was back in 1958. For more than twenty years, we continued this discussion at each of our, only too rare, meetings; sometimes in Helsinki, sometimes in Paris and sometimes on our old Nyiragongo itself.

My last three visits to Nyiragongo were in August 1972, when we spent ten days in its crater, in January 1977, just after its murderous outbreak, and in October 1982. During all these trips, I missed the presence of Thure Sahama, for the specific eruptive activity observed on these different occasions was most probably of great petrological significance, and a first-class petrologist on the spot would have been invaluable. In 1972, in contrast to the quiet lake activity that characterized Nyiragongo when Sahama had visited it in the Fifties and Sixties, it was as stormy, and even stormier, than it had been in 1948 when we had discovered its very existence; in 1977, the volcano had delivered its very first historical outbreak, its lake had been drawn out and, for the time being, Nyiragongo was lava-lakeless; and in 1982, the lava-lake activity had resumed but, for the first time, molten rock infilled the whole area of the 1-kmwide crater, rather than its 350 - to 500 -m-wide inner sink-holes only, as before.

In 1977, Mount Nyiragongo suddenly split open along a main, 20-km-long, N-S trend and a secondary, shorter E-W one. Within 20 to 30 minutes, the whole molten content, several hundreds of metres deep, was drained out
(Tazieff 1977). This eruption was exceptionally short (less than half-an-hour) but even so a considerable volume of magma and lava was spilled out. The extremely fluid flows that escaped from the eruptive fissures spread over the surrounding country side, killing over 1000 people.

About two weeks earlier, another eruption had started, and was still developing on what seemed to be the southwestern foot of Mount Nyiragongo, at a spot named Murara. Indeed, some geologists, and also some would-be volcanologists, attributed it to this very volcano, but the Murara outbreak was in fact a lateral eruption of Mount Nyamlagira (Fig. 1). This was evidenced by:

1 - the geomorphological correlations between the Murara monogenic volcano and its two big, polygenic neighbours, Nyiragongo and Nyamlagira: the gentle slope where the new vent broke open, although much closer to Nyiragongo's than to Nyamlagira's crater, clearly belonged to Nyamlagira;

2 - the volcano-tectonic relationships appear to be closer to Nyamlagira than to Nyiragongo; 3 - Murara's eruptive type was identical to the dozen or so Nyamlagira eruptions I had either investigated or simply observed since 1948 , i.e. an eruptive type that never once appeared on Nyiragongo;

4 - as Thure Sahama later confirmed to me, the petrographic nature at the magma erupted through the Murara vent was identical to the usual Nyamlagira kivites - that is tephritic phonolites - and was decidedly different from the melitite nephelinites that characterize Nyiragongo and which were so swiftly and abundantly spilled out in its brief January 1977 outbreak.

\section{Degree in magma ripeness and eruptive mechanisms}

Two neighbouring volcanoes erupting at the same time is a rare event indeed. One example 


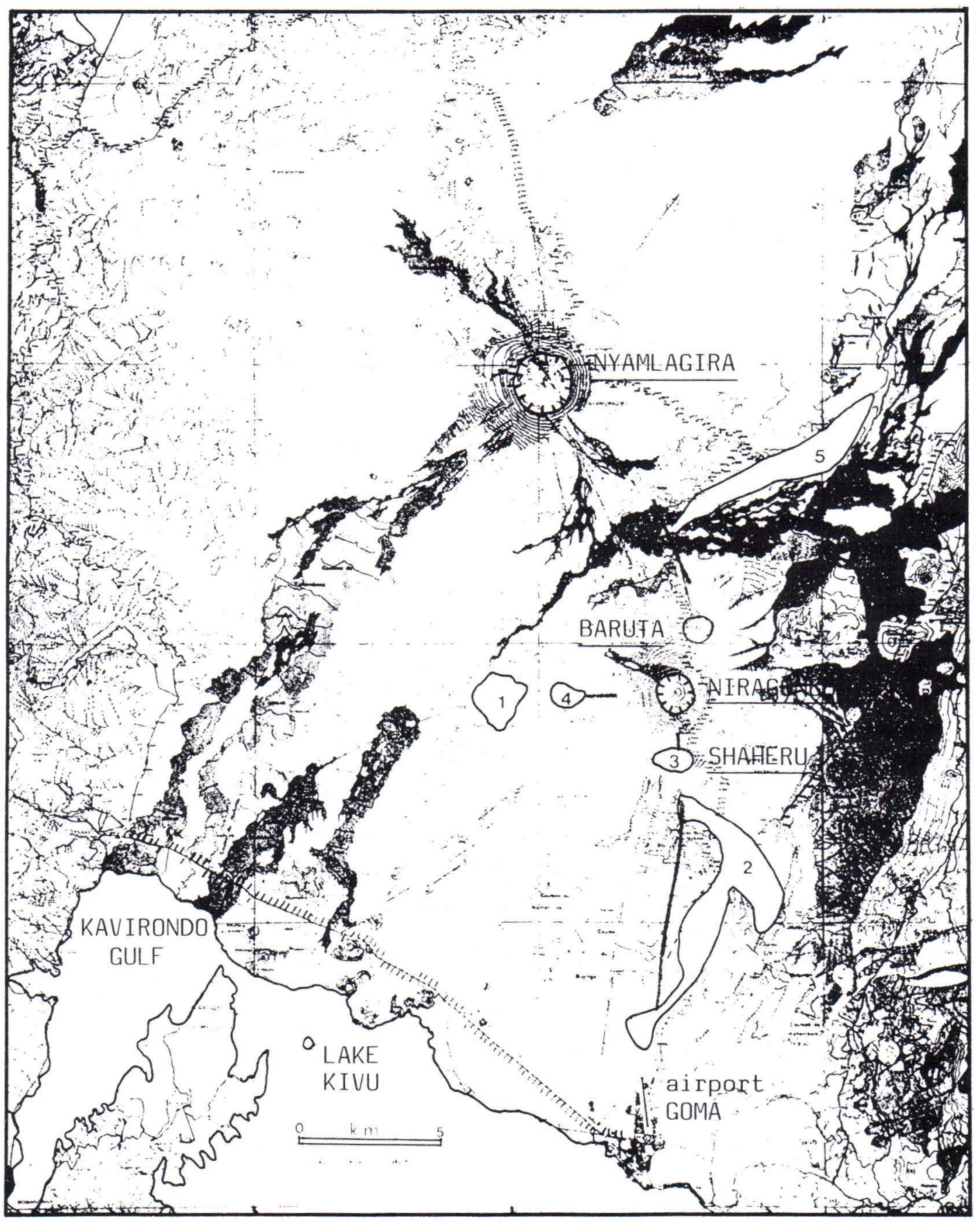

Fig. 1. Sketch map of the lava flows and main fractures of the Niragongo Jan. 10th, 1977 eruption. 1) Murara lava flows (as it was on Jan. 20th), 2) Mudjoga-Kibati-Minigi flows, 3) Shaheru crater flow, 4) Western Nyiragongo (= Niragongo) slope, fracture and flows, 5) Baruta-Mihaga fractures and northern flows. 
was offered when Mount Peleé and the SaintVincent Soufrière, in the Caribbean, erupted simultaneously in May 1902, and a second, more recent one, was in March 1984, when both Mauna Loa and Kilauea broke out together in Hawaii.

For many years I have been convinced - and my talks with Thure Sahama about Nyamlagira and Nyiragongo have confirmed me in my opinion - that even closely situated volcanoes are fed by separate magma bodies. The magmatic »independance» of these two neighbouring volcanoes, the craters of which are less than $15 \mathrm{~km}$ apart but the footslopes override each other, volcanoes located on the same SSENNW fractures set, is evidenced by the chemical and mineralogical differences between the Nyamlagira and the Nyiragongo basanites. Yet, both volcanoes erupted together in 1977, although the Nyamlagira eruption, as already stated, started a fortnight ahead of the Nyiragongo outbreak and lasted for several months, whereas the Nyiragongo one ceased after a matter of minutes only. This discrepancy shows that these twin eruptions, even if they were triggered by some common cause, which seems logical, were otherwise totally different.

My own attempt to explain this unusual simultaneity, as well as the difference in duration, is based on the mechanism that released both these events. I am of the opinion that Nyamlagira delivered a true eruption whereas Nyiragongo was "passively» emptied from beneath its volcanic pile, just as happens a barrel when two of its staves are pulled apart.

As stated in my 1977 paper, I think that both eruptions were generated by a general uplift of the whole Nyamlagira-Nyiragongo area because of the ascent of a comparatively deep-seated magma. This ascent, anteriorly evidenced by the biggest flood ever seen of the Nyiragongo permanent lava-lake over the crater's upper terrace $180 \mathrm{~m}$ ca. below the crater $(3,267 \mathrm{~m}$.a.sl. $)$, probably induced the inflation of both the Nyamlagira and the Nyiragongo volcanic piles.
The first one eventually broke out close to its southermost foot on 23rd December, 1976, and the second one split open two weeks later.

Whereas, as mentioned above, Nyamlagira delivered a normal lateral eruption, which lasted for several months and was exactly similar to all its previously observed eruptions, Nyiragongo produced one of the shortest eruptions ever observed in the world. Within a few minutes, about 20 millions cubic metres of molten rock were poured out, the estimated initial speeds of the flows being about 30 $\mathrm{m}$ : sec. As far as the petrographical similarities and discrepancies in Nyamlagira and Nyiragongo volcanoes are concerned, Thure Sahama easily convinced me that both magmas originated from one single, more deeply seated, parent magma that probably has a higher $\mathrm{K}_{2} \mathrm{O} / \mathrm{Na}_{2} \mathrm{O}$ ratio. He suggested (1973) that the Nyiragongo melilite nephelinites are generated through a gaseous transfer process enriching the parent magma in $(\mathrm{Na}, \mathrm{K})_{2} \mathrm{O}, \mathrm{CaO}$ and $\mathrm{P}_{2} \mathrm{O}_{5}$. Accepting Sahama's hypothesis, I concluded (1977) that the 1976 twin eruptions were due to an uprise of the Nyamlagira-Nyiragongo common parent magma. Monitoring not having been carried out, no inflation was detected of either of the volcanic piles, but the rise in the Nyiragongo's lava-lake level we had observed during the last dozen years or so, a rise that we ascribed to the sole Nyiragongo magma, could possibly have been a manometric result of the deepseated, parental magma ascent.

Even if they were generated by the hypothetical uprise of their common magma, the eventual twin eruptions show, by their petrographic differences, that each volcano was fed exclusively by its own magma. Extensive and careful investigations of the petrography of the widespread lava flows could provide a definitive proof of this assumption, but the petrographical investigations carried out to date already reveal the inferred differences. Other discrepancies similarly plead for simultaneous eruptions of individual magmas: the comparatively long 
duration of the first eruption as against the extremely short duration of the other, and the comparatively large volumes of magmatic gas emitted by the Murara vent as against the insignificant quantity delivered by the Nyiragongo.

A tentative hypothesis can be proposed: the Murara (Nyamlagira) eruption was »active», whereas the Nyiragongo one was »passive». By »active» I mean a normal eruption, in which the magmatic gas phase plays the main role, as opposed to an abnormally "passive» eruption, in which the gas phase is small or almost nonexistent. An »active» eruption displays a large gas-to-magma-output ratio. The magmatic gas phase is the power that pushes the magma upwards by both dramatically reducing its bulk density (and consequently increasing its buoyancy) and mechanically driving it aloft. In contrast, a "passive» eruption like the 1977 Nyiragongo one is not driven upwards by the gas phase but controlled only by gravity: the molten rock stocked in the volcanic pile is simply drawn out through fractures opened at altitudes lower than its own upper level.

That part of the stocked magma (plus, in the case of Mount Nyiragongo, the lava of its lake) which rested above the newly opened vents escaped immediately by mere gravity at speeds depending - all other factors being equal - on the hydrostatic pressure exerted by the liquid column above. The height of this column being close to $1.5 \mathrm{~km}$ in the 1977 Nyiragongo outburst, the hydrostatic pressure was of the order of 4 to $500 \mathrm{~kg} / \mathrm{cm}^{2}$, or 15 kilobars. Together with the very high fluidity of this undersaturated magma, this accounts for the exceptional velocities of the outrushing flows.

Whereas the Murara outburst delivered the lava fountains normally observed and built up a new, classical, cinder cone, the Nyiragongo outbreak showed none of the usual marks of gaseous activity, such as cinder or spattercones, ash deposits, Pelé's hair, etc. .., thus clearly attesting to the lack of a significant eruptive gas phase.
Two mechanisms are suggested as explanations. Sahama postulated that either the parental magma inflated sufficiently to trigger the twin eruptions or that the sole Nyamlagira daughter magma, rising through fractures located close enough to Nyiragongo, induced both the Murara outbreak and a swelling of Mount Nyiragongo large enough to split it open.

The latter hypothesis should not be disregarded simply because it seems hardly credible that the uprise of a volcano's magma could break the neighbouring volcano: as we shall show later, a multi-trend system of wide open fractures most probably extends beneath the whole Virunga mountain range, particularly, beneath the westernmost pair of mountains, i.e. Nyiragongo-Nyamlagira: one of these tectonic trends is oriented north to south and another east to west. Murara, the new vent on Nyamlagira, is located exactly south of its mother volcano's summit caldera and west of its neighbour's large crater with its lava-lake, (see Fig. 1). Murara is thus located at the transection of the EW and NS sets of the multitrending original fracture system; the Nyamlagira magma possibly rose, at least partially, through the EW fracture zone and consequently may have contributed to the swelling of the nearby Mount Nyiragongo; but as the latter eventually split open mainly along the NS tectonic trend, one cannot attribute it to a tensional stress north to south. Further, since Nyiragongo spilled out its own peculiar type of magma, one should conclude that this magma was pushed up either because of its own buoyancy or because of the thrust from beneath of its parent magma. The contemporaneity of the Nyamlagira and Nyiragongo outbreaks induces us to accept the latter hypothesis, and the exceptionally short duration of the Nyiragongo outburst, as well as its »passive» characteristics, indicate that its own magma was not ripe enough to deliver an eruption on its own.

These twin eruptions should therefore be attributed primarily to the parent magma's 
buoyancy. The Nyamlagira magma was also ripe and, helped by the underlying mother magma, delivered a normal »active» eruption. The Nyiragongo magma, in contrast, was not ripe for eruption and was merely drained off by the fractures opened by the swelling of the volcanic piles induced by the uprise of the deep parent magma.

Magma ripeness consists of the vesiculation of the dissolved gas phase. This exsolution relies on several physico-chemical parameters, such as hydrostatic pressure, temperature and molecular concentrations. Magma buoyancy begins with the appearance of the first microbubbles and grows according to the increase in the bubblesto-liquid ratio.

One could ask why the Nyamlagira magma was ripe but not that of Nyiragongo. The answer may lie in the fact that the Nyiragongo magma was continuously degassed through its perennial lava-lake free surface, whereas the Nyamlagira one, deprived of such an exceptional facility, increased its bubble content with time, depending on the evolution of the chemical parameters.

\section{Lava takes mechanisms}

It is worth reminding the reader that Mount Nyamlagira had also contained a permanent lava-lake until it was drained out during the 1938-1940 eruption (Verhoogen, 1939 and 1948). The same happened with Kilauea, in Hawaii, where the over one hundred years old Halemaumau sub-permanent lava-lake did not return after it disappeared in 1924, notwithstanding the volcano's exceptionally frequent eruptions. Rather surprisingly, Mount Nyiragongo on the other hand resumed its lava-lake activity a mere five years after its fifty-years-old lake had been drained out. This is tentatively attributed to its having been drained out "passively», whereas both the Kilauea one in 1924 and the Nyamlagira one in 1938 disappeared during »active» and even, comparatively speaking, very active outbreaks.

Because of atmospheric cooling of the lava, no permanent - or long lived - lava-lakes should exist without continuous renewal of hot fresh magma. An amount of heat equal to the heat lost by radiation should be provided from beneath, and this necessarity entails a two-phase convection system. Such a convection has been noted in all the permanent (or sub-permanent) lava-lakes observed so far: on Halemaumau (Kilauea, Hawaii), on Nyamlagira and on Nyiragongo (Zaire), on Erta'Ale (Ethiopia), and on Mount Erebus (Antarctica).

Now, the only visible part of the convection cell (its upper base) does not usually show any radial currents diverging from a central feeding column like those observed in the laboratory on experimental convection cells. On permanent lava-lakes, only one large current, oriented along one single trend, is usually observed. This can tentatively be attributed to the existence of a feeding fissure that introduces fresh, buoyant magma (or the gas-rich phase) at one end of the lake, and a draining fissure that swallows the de-gassed, cooled, and therefore denser, lava (or the gas-poor phase) at the other end. The almost stupendous perenniality of the surficial currents that we have witnessed for years and years in the lava-lakes of Nyiragongo, Erta'Ale and Erebus, persuades me of the similar perenniality of an underlying open fractures system; yet, monitoring of both the activity and the morphology of these lava-lakes has convinced me that the division of the convection cell into apparently separated fractures, one for the rising magma, the other for the subsiding lava, if it ever actually exists, is restricted to the surface only. Consequently, I suggest that a wide, probably downward widening, system of underlying inter-crossing fractures generates a vertical shaft wide enough to allow a two-phase convection to occur.

The former, solidified lava »island» of Nyiragongo, the topography of what are apparently 
two lakes on Erta'Ale (where only one actually exists), and the morphology of the Mount Erebus lava pit, plead for the opinion that lava-lakes are usually mere windows, or sky-lights, of the upper area of a much larger convection-cell. The resuscitated lava-lake of Nyiragongo, which occupied the whole crater in 1982, (over $1 \mathrm{~km}$ in diameter), demonstrated this beautifully, with a centrally located magma column feeding radially diverging lava flows, and a circumference of thicker, denser, and consequently subsiding, cooled-down lava (Tazieff 1984). This plain image will probably be altered pretty soon because peninsulas and/or islands of solidified lava will form at spots where, for various possible morphological reasons, the subsidence of lava will be prevented; such islands and peninsulas will progressively grow up and eventually hide large parts of the molten lake's surface, as happened on Nyiragongo and is currently happening in the lakes of Erta'Ale and Mount Erebus.

So, as recently demonstrated by Nyiragongo, the convection that allows permanent lava-lake activity should be due to one sufficiently wide structure rather than to a system of two (or more) separate fractures: one allowing the gasrich magma to keep rising, the other permitting the denser lava to subside. On the other hand, the too frequently supposed system of a cylindrical channel connecting the crater with a similarly inferred spheroidal reservoir has not been demonstrated to date. On the contrary, all volcano feeding systems, observed or inferred, appear to be controlled exclusively by intersecting fractures.

The so-called »fissure eruptions» seems to be restricted to fluid lavas and are delivered by fractures opened along one single trend (Fig. 2). In contrast, polygenic central volcanoes, erupting either fluid or viscous lavas, seem to be located exclusively at the crossing of at least two differently oriented fracture systems. It may be supposed that the duration of eruptive activity phases, all other factors being equal, is related to the number of intercrossing fractures and to the width of the resulting chimney. If this is true, permanent lava-lakes, because of the necessity of a sufficiently large free space to allow two-phase convection, should be controlled by a multitrending fissure system.

This is what is actually happening in the three volcanoes with lava-lakes that I have investigated (and the only three currently existing on Earth): Mount Erebus is apparently located at the intersection of EW, NS and SW trends (Tazieff 1984); Erta'Ale's crater shows at least two fracture directions: the main SSE-NNW Red

Fig. 2. Typical fissure eruption of oceanic basaltic flows in the axis of the Afar-mid-oceanic rift (Red Sea Gulf of Aden structure), at the southeastern end of the Erta'Ale volcanic range.

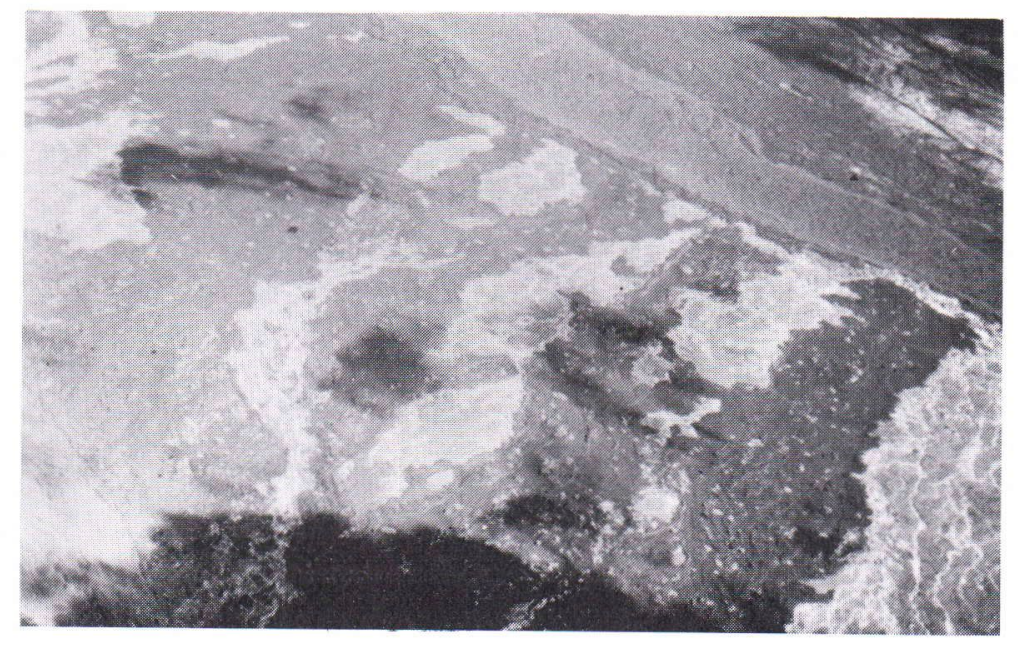


Sea major tectronic trend and a subsidiary $\mathrm{N}-\mathrm{S}$ one; Mount Nyiragongo (and most probably also its twin volcano, Mount Nyamlagira, is situated at the crossing of four directions: the $\mathrm{N}-\mathrm{S}$ one of the western branch of the great Rift Valley of East Africa local trend, evidenced by the Shaheru-Nyiragongo-Baruta alignment, the $\mathrm{E}-\mathrm{W}$ one of the general trend of the Virunga volcanic range, (both trends were activated during the Murara-Nyiragongo twin eruptions) (Fig. 3); the SE-NW direction of the important fractures zone linking Nyiragongo and Nyamlagira, and a barely conspicuous NE-SW one, detected in 1982 (Tazieff 1984).

If the above hypothesis is accepted, the fact that lava-lake activity resumed in the Nyiragongo crater a few years only after the lake had been drained off could be attributed to the fact that this outbreak was a "passive» one and that the intercrossing fractures that provide the feeding shaft had not been sealed by a plug of comparatively cooled and consequently coherent, solidified magma, but had been only loosely infilled by incoherent fallen rocks from the crater walls. Such an infilling, unlike a solid, homogeneous sealing, is easy for a rising magma column to break open. This would account for the early revival of lava-lake activity in Nyiragongo, in contrast to that of Halemaumau, which disappeared in 1924, and of Nyamlagira, which vanished in 1938. For activity to resume in these two volcanoes, more than simply one of the intercrossing fissures must be re-opened, as probably happened at each of the numerous (several a decade) eruptions that both have delivered since their lava-lakes disappeared. The wide shaft, without the presence of which large scale convection could not proceed, requires the re-opening of at least two sets of intercrossing feeding fractures.

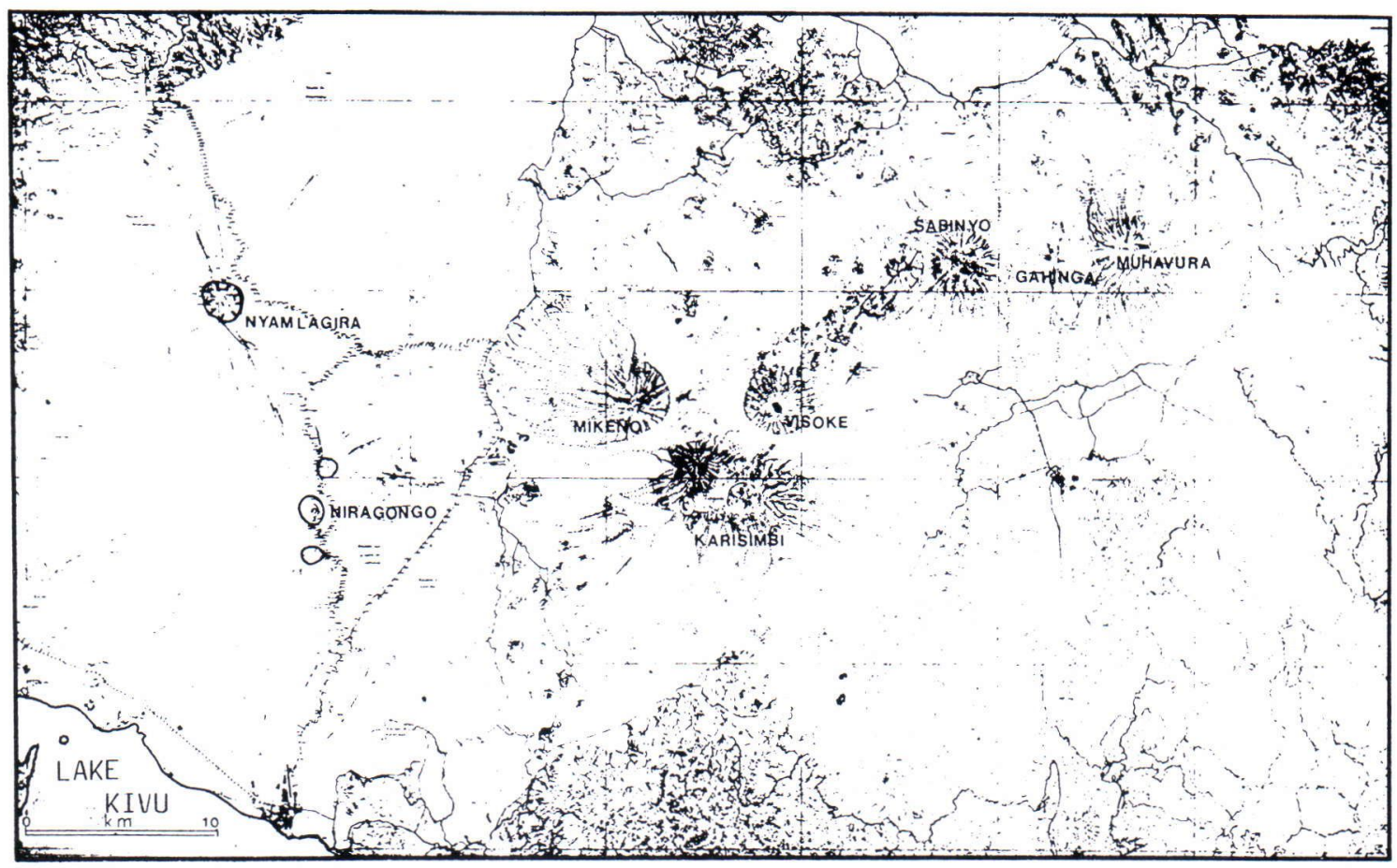

Fig. 3. The Virunga volcanic field. 


\section{RESUME}

Le comportement du Niragongo avant et après sa brève éruption du 10 janvier 1977, comparé à celui des deux autres volcans à comporter actuellement un lac de lave permanent, l'Erta'Alé et l'Erebus, induit à supposer que la large cellule de convection nécessaire à alimenter en magma frais un tel lac ne peut se former que lorsque des fractures largement ouvertes se recoupent en un même endroit, ménageant ainsi une cheminée d'alimentation suffisamment vaste pour permettre le phénomène. A la différence du Halemaumau, dont le lac de lave disparut lors de l'éruption du Kilauea en 1924 et n'a pas été reconstitué jusqu'ici, et du Nyamlagira, dont le lac fut draîné lors de la longue éruption de 1938 - 1940, le Niragongo a retrouvé cet exceptionnel type d'activité cinq années seulement après que son lac eut, lui aussi, été draîné. L'hypothèse avancée ici est que l'éruption de janvier 1977 était »passive» et celles de 1924 et 1938 étaient »actives». Par actives, nous voulons dire dues à l'éruptivité propre du magma, c'està-dire à la vésiculation de sa phase gazeuse, originellement dissoute dans le bain de silicates en fusion. L'éruption du 10 janvier 1977 fut au contraire passive, en ce sens que la lave du lac et le magma sous-jacent s'écoulèrent à l'extérieur du cône volcanique lorsque celui-ci se fêla, selon deux directions conjuguées, non sous la poussée de son propre magma, qui n'avait pas atteint, par vésiculation, sa maturité éruptive, mais sous celle du magma parental sous-jacent, commun au Niragongo et au volcan voisin, le Nyamlagira.

Cette hypothèse permet d'expliquer l'aisance avec laquelle le magma du Niragongo, une fois sa force ascensionnelle reconstituée par vésiculation, s'est frayé un passage large assez pour permettre la convection: les fractures béantes qui s'entrecroisent sur son axe n'étaient en effet encombrées que par un remplissage fort lâche d'éboulis de parois, alors que la »cheminée d' alimentation» du Kilauea et du Nyamlagira se trouve bloquée par un culot de lave massive, solidifiée à la fin de leur éruption »active».

Les très nombreuses éruptions que ces deux volcans délivrent depuis se font chaque fois par la réouverture d'un seul jeu de fractures. Au Niragongo par contre, dont la cheminée n'avait pas été scellée, l'ascension du magma a pu reprendre dans des conditions géométriques qui permettent la convection, indispensable à la genèse d'un lac de lave permanent. Les éruptions volcaniques habituelles ne présentent jamais le phénomène de la convection bi-phases.

\section{References}

Barberi, F. \& Varet, J., 1970. The Erta'Ale volcanic range. Bull. Volcanol. 34, 848-917.

Kyle, P. R. \& Cole, J. W., 1974. Structural control of volcanism in the McMurdo volcanic group. Antarctica. Bull. Volcanol. 38, 16-25.

Sahama, T. G., 1962. Petrology of Mount Nyiragongo, a review. Trans. Edinburgh Geol. Sci. 19, 1-28.

Sahama, T. G., 1973. Evolution of the Nyiragongo magma. J. Petrol. 14 (1), 38-48.

Tazieff, H., 1977. An exceptional eruption: Mount Niragongo Jan. 10th 1977. Bull. Volcanol. 40, 189-200.

Tazieff, $H$., 1984. Mount Niragongo: renewal activity of the lava-lake. J. Volcanol. Geotherm. Res. 20, $267-280$.

Verhoogen, J., 1939. New data on volcanic gases: the 1938 eruption of Nyamlagira. Am. Journ. Sci. 237, 656-672.

Verhoogen, J., 1948. Les éruptions de 1938-1940 du volcan Nyamlagira. Inst. Parcs Nationaux Congo Belge 1, $1-187$. 